\title{
Ambient radioactivity on a reconnaissance study tour of Bratislava - Dubai- Kathmandu - Nepal Himalaya
}

\author{
Andrej MOJZEŠ ${ }^{1, *}$ (D), Miroslav BIELIK ${ }^{1,2}$ (D), František MARKO ${ }^{1}$ (D), \\ Ján MADARÁS ${ }^{2}$, Kamil FEKETE ${ }^{2}$ (D) Pavol SIMAN² (D), \\ Juraj PAPČO ${ }^{3}$ (D), Ashok SIGDEL ${ }^{4}$ (D), Subash ACHARYA ${ }^{4}$ (D) \\ ${ }^{1}$ Comenius University, Faculty of Natural Sciences, \\ Ilkovičova 6, SK-84215 Bratislava, Slovak Republic \\ ${ }^{2}$ Slovak Academy of Sciences, Earth Science Institute, \\ Dúbravská cesta 9, SK-84005 Bratislava, Slovak Republic \\ ${ }^{3}$ Slovak University of Technology, Faculty of Civil Engineering, \\ Radlinského 11, SK-81005 Bratislava, Slovak Republic \\ 4 Tribhuvan University, Central Department of Geology, \\ Kirtipur, Kathmandu 44618, Nepal
}

\begin{abstract}
Ambient radioactivity originates mainly from natural sources and materials (rocks and soils, building and other man-made materials, and cosmic radiation), and less frequently from artificial radionuclides. A geoscientific comparative study of the geological structure of the Alpine-Carpathian and Himalayan mountain range systems primarily focused on the area of structure geology, tectonics, stratigraphy and petrology in connection with the in-situ sampling of magnetic susceptibility and radioactivity at rock outcrops was also utilized to perform continual monitoring and acquisition of the equivalent gamma dose rate values in the air of the surrounding environment. A GeigerMüller dosimeter was used for continual recording at a sampling frequency of 2 minutes. Simultaneously, a data-logger was used to record the ambient temperature, humidity and pressure values at a sampling frequency of 4 minutes. The measurements cover the entire tour, in particular, Bratislava, Slovakia (42.5 hours) - flight (5.75 hours) - Dubai, United Arab Emirates (11.3 hours) - flight (4 hours) - Kathmandu, Nepal (12.2 days) - flight (4.8 hours) - Dubai (9 hours) - flight (6.25 hours) - Bratislava (48 hours) from 27 March 2019 to 15 April 2019. The levels of ambient radioactivity belonging to different environments are compared and discussed in the contribution. The differences are based on both the chemical composition of the geological basement and adequate building materials and the cosmic contribution. The results of the measurements show higher values of ambient radioactivity for the Nepal environments and lower values for Dubai, in comparison with Bratislava, and by far the highest, but safe values for international flights attributed to the high portion of cosmic radiation. The contribution was generated within the ambit of the research project APVV-16-0146 WECAFARE (WEstern CArpathians FAults
\end{abstract}

\footnotetext{
${ }^{*}$ corresponding author: e-mail: andrej.mojzes@uniba.sk
} 
REsearch) "Multidisciplinary research of the geophysical and structural parameters and environmental impacts of the faults of the Western Carpathians" thanks to the financial support of the Slovak Research and Development Agency.

Key words: applied geophysics, radioactivity, gamma dose rate, comparative geological study

\section{Introduction}

The instrumental data collection of physical properties of the geological environment creates the core of geophysical measurements and significantly contributes to its more complete cognition. That is also true for the case of the Western Carpathians faults research project under the name "Multidisciplinary research of the geophysical and structural parameters and environmental impacts of the faults of the Western Carpathians". The international cooperation of experts and an effort to correlate and update knowledge led to the realization of a multidisciplinary geoscientific comparative study of the geological structure of the Alpine-Carpathian and Himalayan mountain systems in the form of an intensive 9-day field research stay in the area of Nepal Himalaya. A structure-geological, tectonic, stratigraphic and petrologic investigation was also accompanied by in-situ sampling of magnetic susceptibility and radioactivity at rock outcrops and by collecting the small-volume rock samples. Moreover, regarding radioactivity measurement issues, the so-called continual monitoring and recording of the equivalent gamma dose rate values in the air of the surrounding environment during the 20-day stay on the tour Bratislava (Slovakia) - Dubai (United Arab Emirates) - Kathmandu (Nepal) - Nepal Himalaya - Kathmandu - Dubai - Bratislava was carried out. The issues of the analysis of the radioactivity rock outcrops were thus enlarged by problems of background radioactivity and the contribution of cosmic radiation during the plane flights themselves. This article provides an evaluation and comparison between ambient radioactivity during the constituent trip periods.

\section{Study aim}

The goals of study were:

- to carry out, as circumstances allowed, complete continual data collection 
on radioactivity in the form of the equivalent gamma dose rate in the air during the entire tour, together with the ambient temperature, humidity and air pressure data;

- to process and evaluate such data in terms of their changes during the tour due to particular environmental differences;

- to compare the levels of ambient radioactivity and meteorological variables between constituent tour stages; and

- to try to identify and distinguish the sources of the changes of the measured variables during the tour.

The sources of the equivalent gamma dose rate in the air were natural radionuclides present in the surroundings, either the geological or generally natural environs, or in man-made materials (building, technological and other), where cosmic radiation presents a permanent contribution. To a lesser extent, it is not possible to rule out the presence of artificial radioactive sources. This article does not include a detailed analysis of the composition of radioactive sources (e.g. by the gamma-ray spectrometric measurement) or an evaluation of the results of the detailed sampling of the equivalent gamma dose rate at individual rock outcrops.

\section{Methods and equipment}

The continual measurements and data collection of the equivalent gamma dose rate in the air were carried out by dosemeter based on the Geiger-Müller detector at a recording frequency of 2 minutes. The GAMMA-SCOUT instrument with a registration and recording of gamma rays in an energy range of $0.03-3 \mathrm{MeV}$ was used for measurement purposes.

The continual measurement and data collection of the ambient air temperature, humidity and pressure were carried out by the multifunction datalogger VOLTCRAFT THP180 at a recording frequency of 4 minutes.

\section{Study areas and their geological settings}

The measurements were taken continuously at the above-mentioned recording frequency on the Bratislava - Dubai - Kathmandu - Pokhara - Baglung - Kalopani - Kagbeni - Muktinath - Tukuche - Beni - Pokhara - Kath- 
mandu - Dubai - Bratislava tour from 27 March 2019 to 15 April 2019 (20 days). The reconnaissance study on the mentioned tour itself (Fig. 1) lasted 16 days from 29 March 2019 to 13 April 2019, and the direct field geological research in the Nepal Himalaya along the line of the Kathmandu - Pokhara - Baglung - Kalopani - Kagbeni - Muktinath - Tukuche - Beni - Pokhara - Kathmandu geological transect (Fig. 2) lasted 9 days from 1 April 2019 to 9 April 2019.

Due to the length of the planned field geological profile, i.e. approx. 200 $\mathrm{km}$ of the Kathmandu - Pokhara leg and approx. $175 \mathrm{~km}$ of the Pokhara - Muktinath leg, the field survey was performed with the help of 2 field cars (9-member research team) in the form of numerous stops at selected localities along with walking examinations of geological objects.

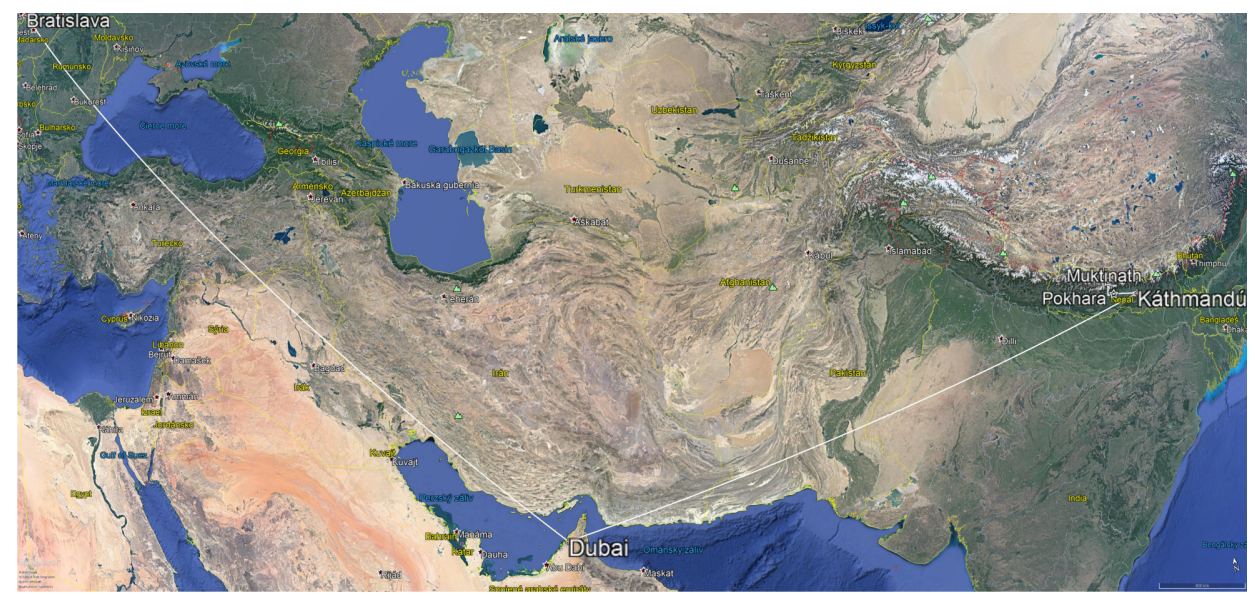

Fig. 1. Illustration of the entire tour in the Google Earth application.

In terms of covered distance, there were two different means of transportation: air transport comprising of 4 international flights (Bratislava Dubai and Dubai - Kathmandu, Kathmandu - Dubai, Dubai - Bratislava) with large distances (thousands of kilometres) covered in a relatively short time (hours) and car + walking transport (in Bratislava, Dubai and Nepal) with short distances (up to hundreds of kilometres in Nepal) covered in a substantially long time (days). For this reason, the next short geological characterization is given for those tour parts covered by car and foot only, i.e. the Bratislava and Dubai areas and the field study trail in the Nepal 


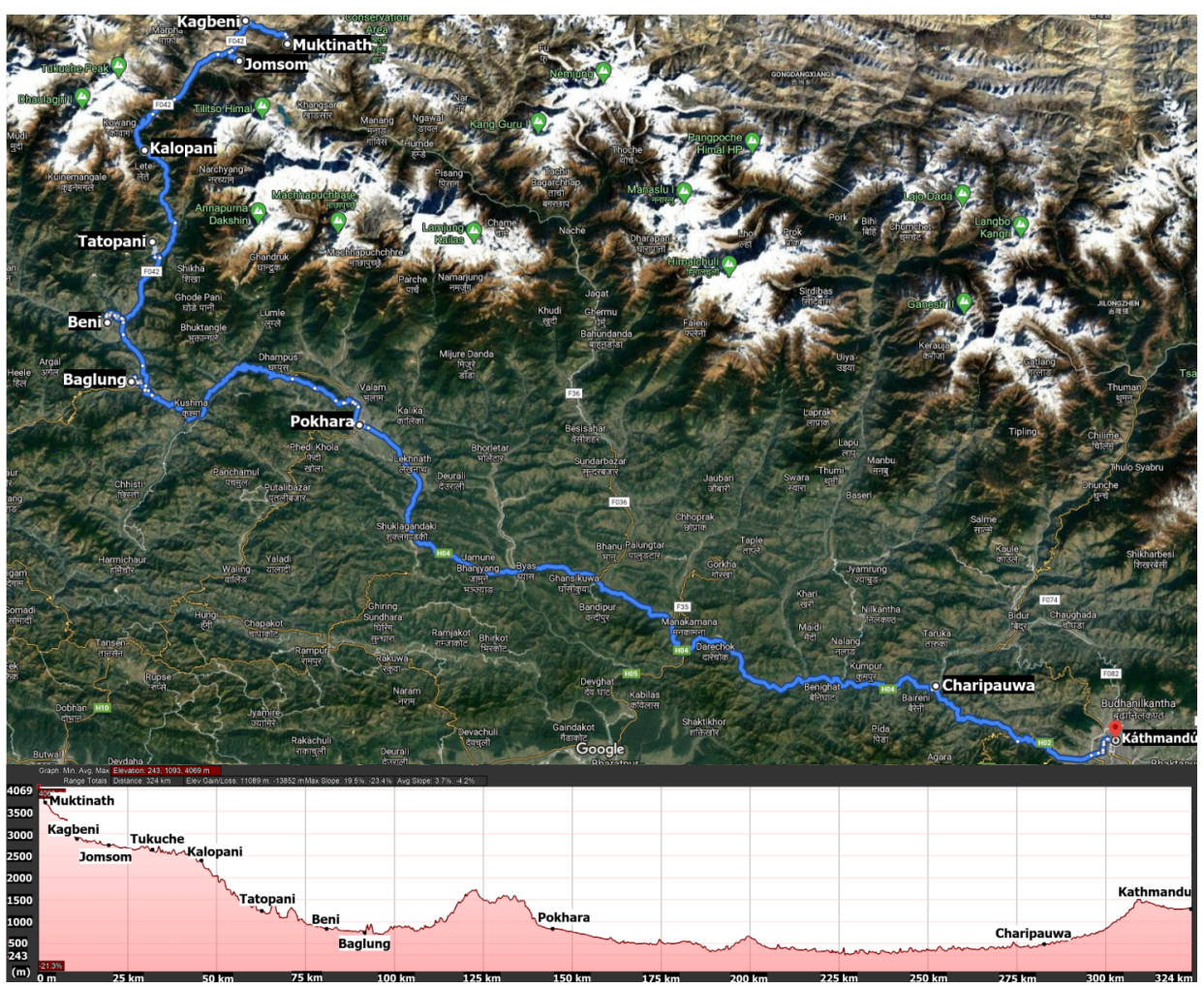

Fig. 2. Illustration of the field study geological transect (blue line) through the Nepal Himalaya and its height profile in the Google Maps and Google Earth applications.

Himalaya.

\subsection{Bratislava (Slovakia)}

The referred area of the eastern part of the city at the airport site is entirely comprised of Quaternary (the Late Pleistocene - Holocene) fluvial sediments (Fig. 3) in the form of lithofacially undivided alluvial clay soils and sandy to gravel soils (map index "fhh"), as well as sandy gravel and sand (map index "fšs"). Postglacial deposits of alluvial sediments make up a substantial part of the fine-grained sedimentary surface cover of the sandy-gravel formation of the bottom accumulation of water flows (Geological map of Slovakia 1:50 000, 2013). 


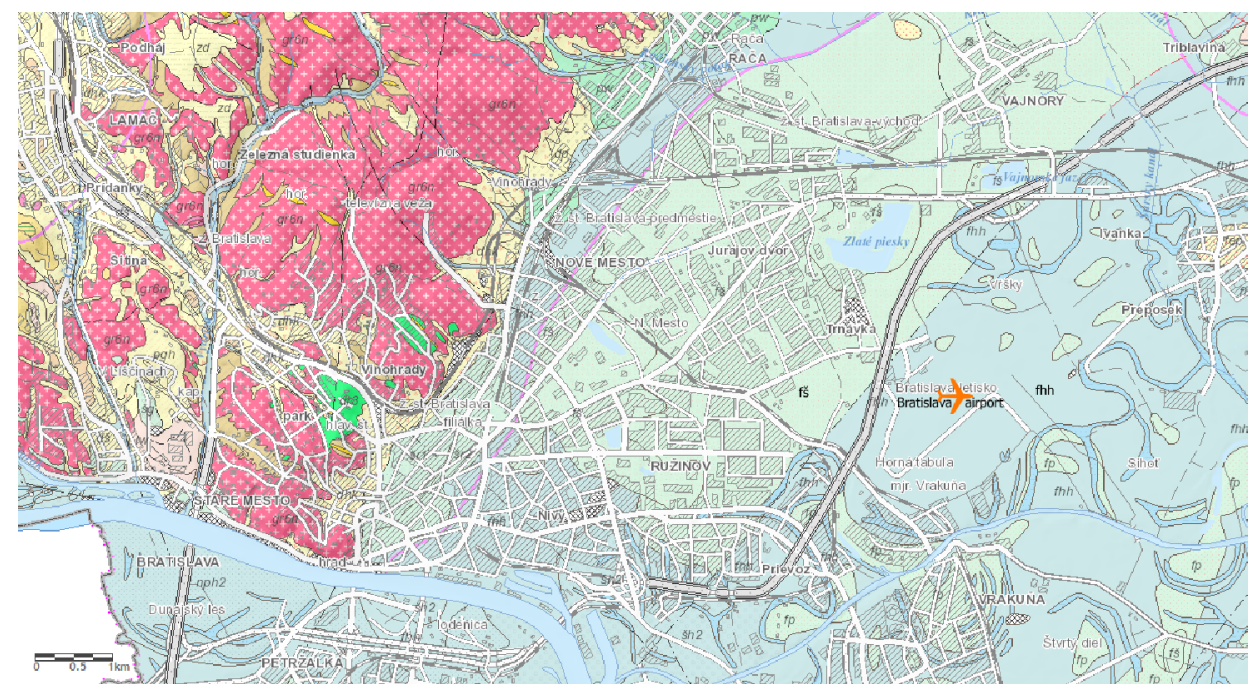

Fig. 3. Section of the geological map of the eastern part of Bratislava at the international airport localization (Geological map of Slovakia 1:50 000, 2013).

\subsection{Dubai (United Arab Emirates)}

The surface geology of the United Arab Emirates is concealed under a cover of sand (Fig. 4). Outcrops are confined only to the eastern part where the Oman Mountains form part of that region. The sands form dune ridges reaching heights of $150 \mathrm{~m}$ inland. Plain gravel areas - the so-called "desert floor", separate the dune ridges. Evaporatic flats (sabkha) dominate the coastal plains, which extend more than $80 \mathrm{~km}$ southwards into sand deserts. Consequently, the geology of this area is based exclusively on subsurface information (Irani, 2001).

Superficial deposits in the major urban areas in the emirates of Dubai, Sharjah and Ajman comprise the Quaternary fluvio-aeolian, aeolian and shallow marine deposits. Over much of the area, anthropogenic activity has resulted in the widespread deposition of made ground, including engineered fill. The Quaternary superficial deposits are underlain by variably calcareous and dolomitised sandstones, siltstones and conglomerates of the Barzaman Formation and weak mudstones, siltstones and gypsums of the Gachsaran Formation. In heavily urbanised areas, the extent of made 
ground, the lack of exposure and the restricted nature of many of the site investigation reports means that the geological line-work was based on aerial photographs and satellite imagery taken prior to development (Price et al., 2012).
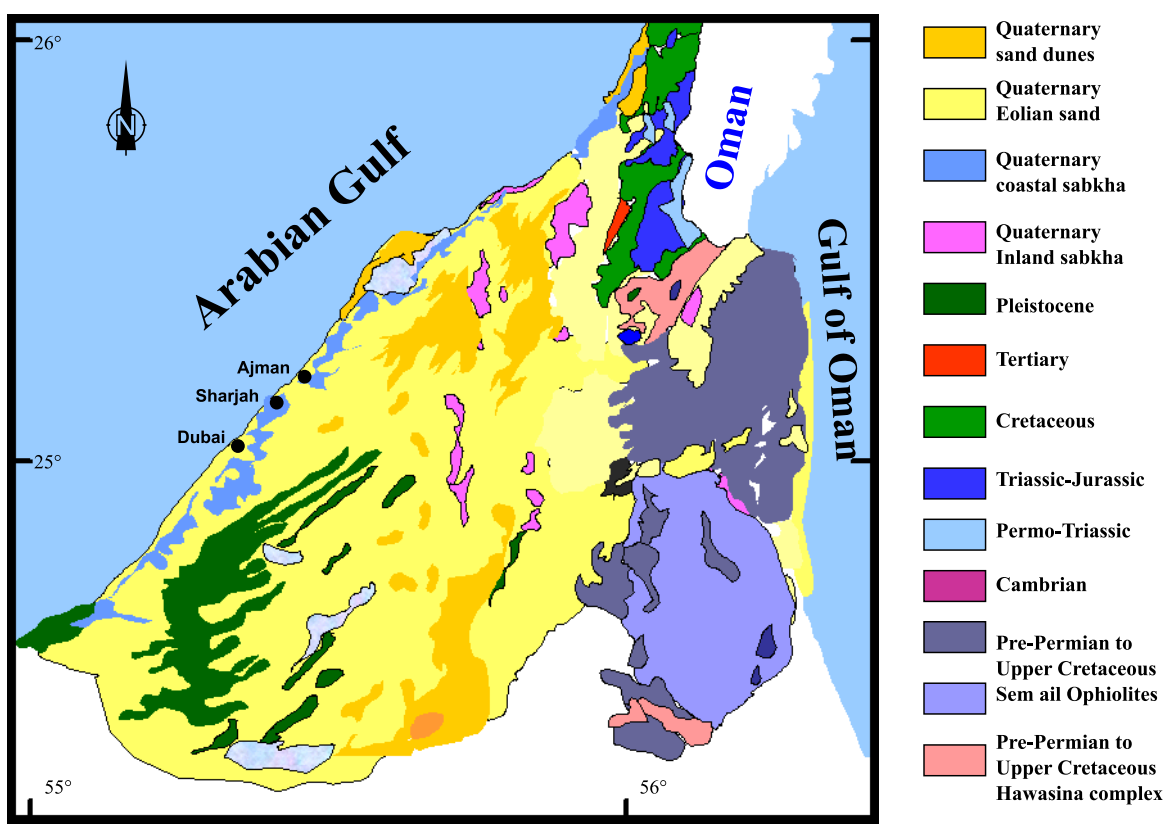

Fig. 4. Simplified geological map of the northern part of UAE (Internet 1, modified and Internet 2).

\subsection{Kathmandu - Muktinath (Nepal)}

The geological transect was very suitably selected considering the characteristic latitudinal features of the geological structure of Nepal with five fundamental NW-SE geological zones ranging from south to north in the following order: Terai and Bhabar Zone, Siwaliks and intermontane basins, Lesser Himalaya, Higher Himalaya and Tethys Himalaya (Dhital, 2015; Fig. 5). The first approximately $300 \mathrm{~km}$-long part of the tour between Kathmandu and Beni followed a general NW-SE direction of geological units, which is why it runs mostly in the Lesser Himalaya zone, except for the first section - the approximately $70 \mathrm{~km}$-wide Kathmandu surroundings with a compli- 
cated geological structure of the Kathmandu Group belonging to the Higher Himalaya zone (Figs. 5, 6a). The Lesser Himalaya is basically composed of Proterozoic, mostly sedimentary (limestone, dolomite, shale and conglomerates) and low-grade metamorphic rocks (quartzites, phyllites, slates). The Kathmandu Group is composed mostly of Pre-Cambrian to Devonian metamorphic rocks (phyllites, micas and quartz schists, quartzites and sandstones) (Fig. 6b).

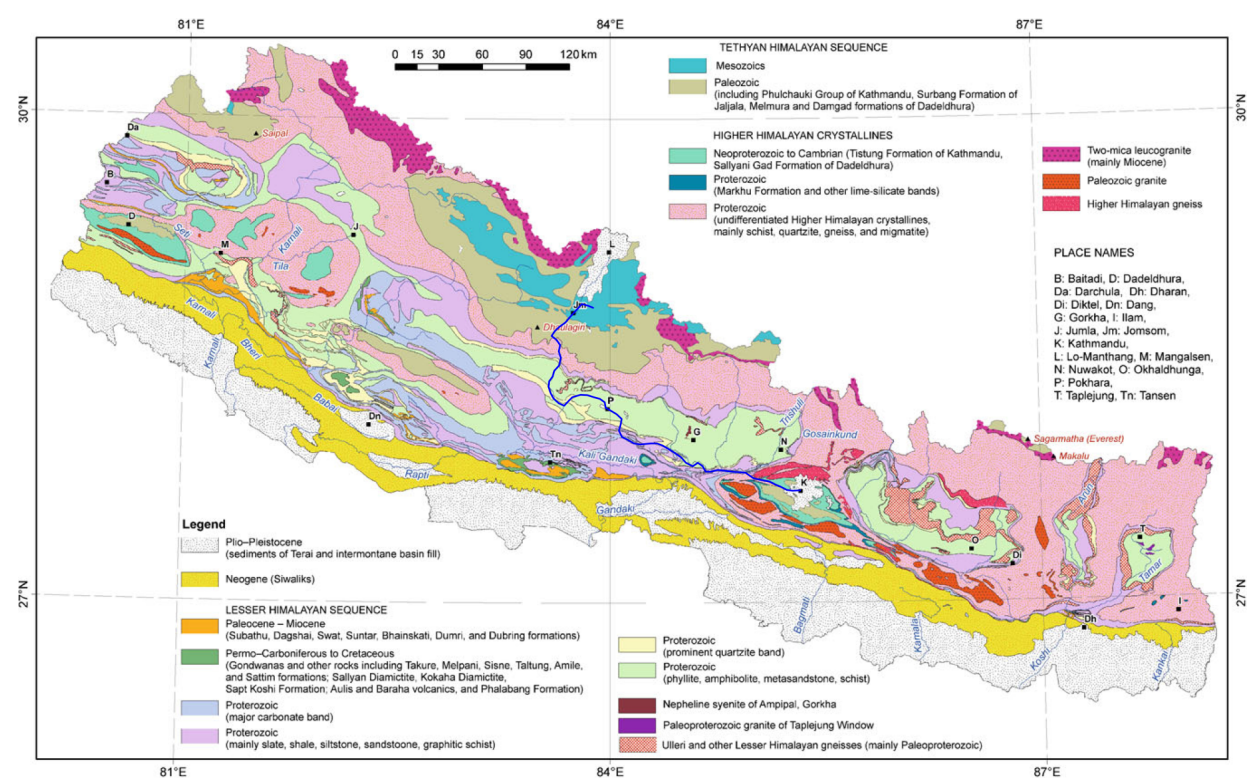

Fig. 5. Simplified geological map of Nepal (Dhital, 2015; supplemented by the blue line of the geological transect).

The second part of the tour between Beni and Muktinath (around $112 \mathrm{~km}$ ) followed the Kali Gandaki River valley in a SSW-NNE direction across geological zones, and thus it cuts the Lesser Himalaya zone, the Main Central Thrust (MCT), the Higher Himalaya zone, the fault South Tibetan Detachment System (STDS) and ends in the Tethys zone (Muktinath) (Figs. 5,6a). The Lesser Himalaya zone is, intersected by the tour approximately in the part between Beni and Tatopani, and similar to the first part between Charipauwa and Beni, it is mostly composed of the Proterozoic low-grade metamorphic rocks (quartzites, phyllites, carbonaceous slates) and sedimentary rocks (green shales, compact dolomites, dolomitic limestones, sandstones 


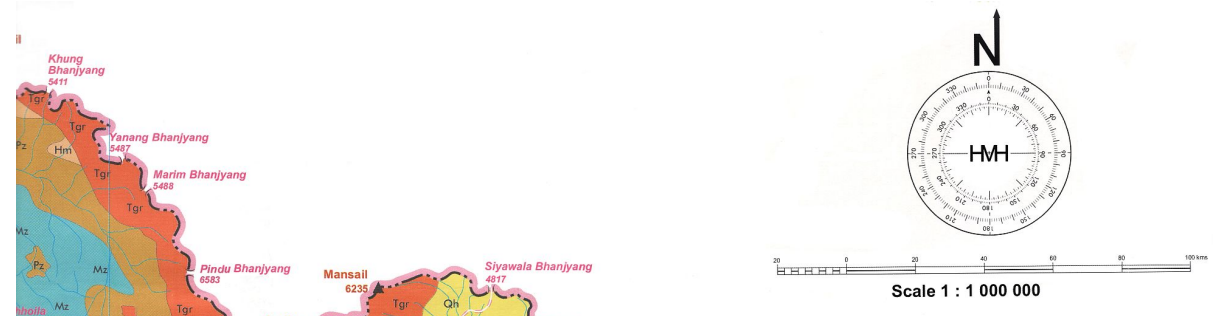

C H I N A

( $T$ I B E T )

I N D I A

Fig. 6a. Section of the geological map of Nepal (Himalayan Map House Pvt. Ltd., 2014). 


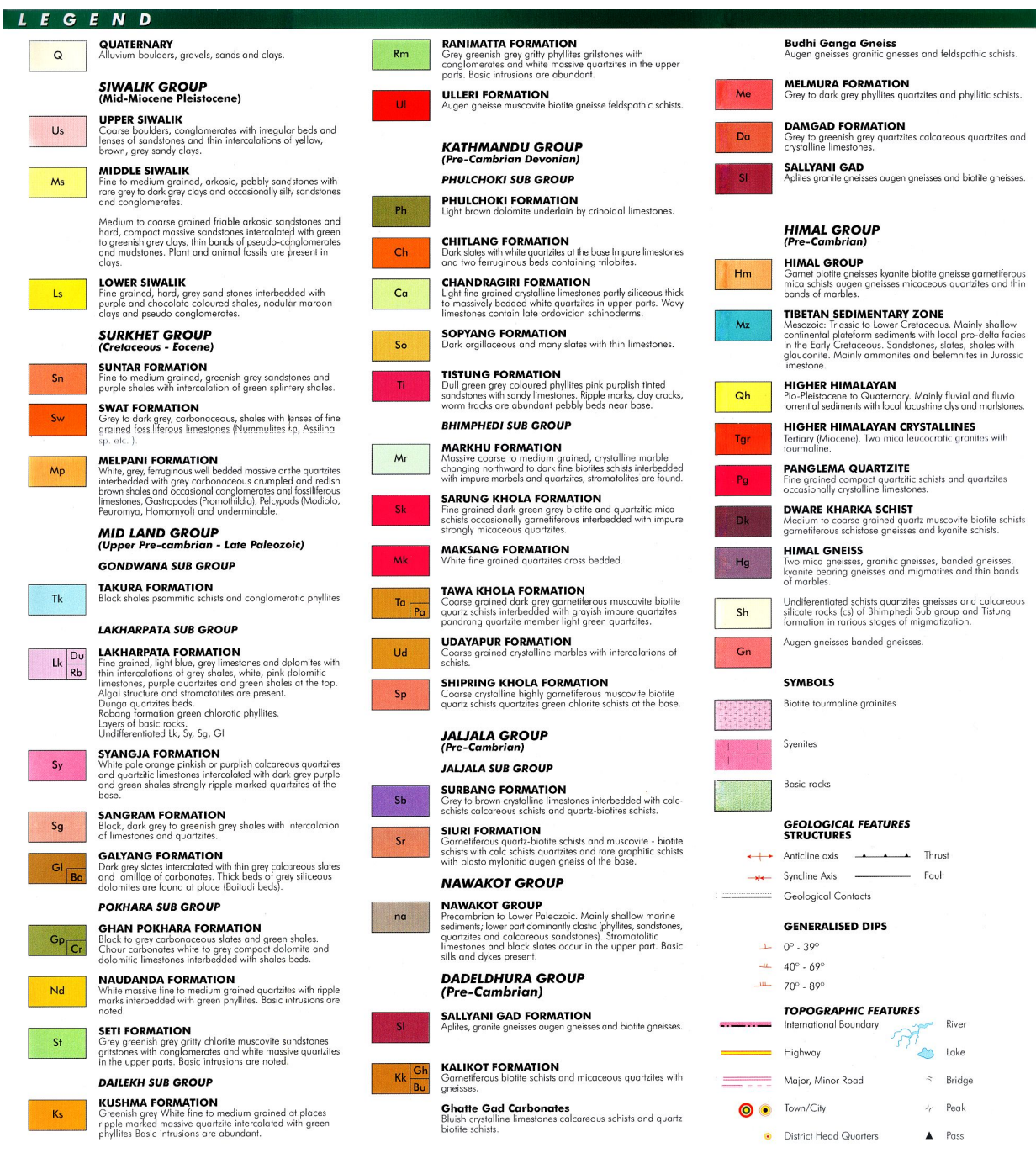

Fig. 6b. Legend of the geological map of Nepal (Himalayan Map House Pvt. Ltd., 2014).

and gritstones) (Fig. 6b). Generally, the grade of metamorphism increases from the foreland (south) to the hinterland (north) (Dhital, 2015, p. 65).

The Main Central Thrust (MCT) was intersected in the area of the village of Dana near Tatopani. This fundamental thrust structure repre- 
sents the boundary between the underlying faintly metamorphosed Lesser Himalaya succession (south) and overlying Higher Himalayan crystallines (north) (Dhital, 2015, p. 199). The MCT comprises a wide zone of mylonitic rocks (fylonite) Proterozoic phyllites, quartzites and carbonates. The locally abundant presence of carbonate - quartzite veins and the remobilization of ferric oxides (limonitization), refers to fluid penetration in this zone. The increased seismicity, but also numerous natural thermal springs in the vicinity of the village of Tatopani (warm water in translation), also refer to recent activity of the tectonic zone.

The Higher Himalaya zone, between the villages of Tatopani and Kalopani, is composed of Proterozoic crystallines made up of medium to high-grade schists, quartzites and marbles together with augen and banded gneisses, migmatites and granites (Dhital, 2015, p. 199) (Fig. 6b). The Higher Himalayan crystallines are characterized by inverted metamorphism towards their base and a normal Barrovian type of metamorphism towards their top. The grade of metamorphism in the Higher Himalayan crystallines decreases progressively from the hinterland (north) towards the foreland (Siwaliks). Also, their metamorphic grade sharply diminishes towards the Tethyan sedimentary succession (Dhital, 2015, p. 197).

The Higher Himalayan crystallines are frequently truncated to the north by a system of normal faults called the South Tibetan Detachment System (STDS). This fault system was intersected in the area of the village of Kalopani. On the surface, the detachment is a discontinuous fault system with one or more splays. In some instances, it is represented by a shear zone (Dhital, 2015, p. 197). The South Tibetan Detachment System separates the medium to high-grade metamorphic rock of the Higher Himalaya from an overlying sedimentary or low-grade metamorphic secession of the Tethys Himalaya.

The last, most remote part of the tour between Kalopani - Jomsom Kagbeni - Muktinath was in the Tethys Himalaya zone. The Tethyan Himalayan sequence mainly occupies the south periphery of the windswept Tibetan Plateau. The Tethyan rocks are made up of a variety of terrigenous and carbonate sediments, such as sandstones, siltstones, dolomites, limestones and shales (Fig. 6b). They range in age from Cambrian to Eocene. They are strongly folded and faulted, but conformably overlie the Proterozoic succession of the Higher Himalaya. Their grade of metamor- 
phism generally increases from west to east. The Tethyan sediments have lateral changes and strong facies differences. The rocks are intricately folded and frequently verging due north, that is, opposite to the Higher and Lesser Himalayan successions. There are few Paleozoic remnants on top of the Higher Himalayan rocks (Dhital, 2015, p. 285).

\section{Results and discussion}

\subsection{Overview}

The results of the parallel recording of temperature, humidity and pressure of atmospheric air are presented in Fig. 7, while the overall results of ambient radioactivity recording on the Bratislava - Dubai - Nepal - Dubai Bratislava reconnaissance study tour in the form of the equivalent gamma dose rate in the air from 27 March 2019 to 15 April 2019 are presented in Fig. 8. The graphs of the measured variables are presented in a time course, not a distance course. The changes in single variable courses are evident and easily readable in both figures and considering the fact that the path of the trips from Bratislava to Muktinath and back was almost identical; the curves are characterized by an almost mirror image with the centre in the most remote point of the tour - the Muktinath monastery and trekking ascent to the altitude of $4100 \mathrm{~m}$ a.s.l. in the Annapurna massif. This fact illustrates the satisfactory sensitivity of the instruments, the repeatability of their measurements and the stability of the meteorological conditions during the entire tour.

\subsection{Meteorological parameters}

From among the meteorological variables (Fig. 7), barometric pressure bears the highest information value as temperature and humidity were often influenced by the datalogger placement in baggage, the means of transportation or the indoor environment in dwellings.

The overall barometric pressure course (Fig. 7) reliably documents the dependence on altitude. Although altitude was not recorded, the pressure curve shows an evident difference between the low-lying regions of Bratislava (around $130 \mathrm{~m}$ a.s.l.) and Dubai (around $15 \mathrm{~m}$ a.s.l.) and the mountainous areas of the Nepal Himalaya. Also, the periods of four international 


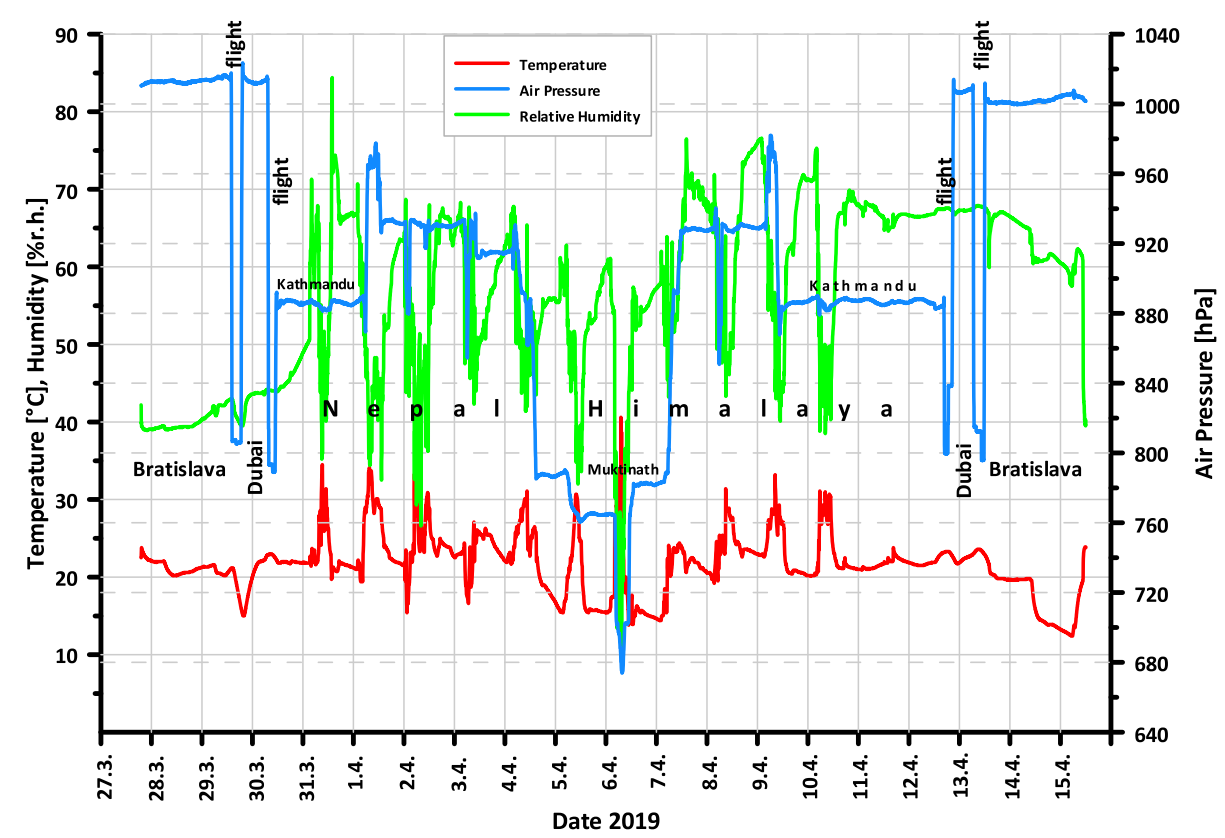

Fig. 7. Time course of meteorological parameters logged during the entire trip.

flights (Bratislava - Dubai, Dubai - Kathmandu and back) can be sharply distinguished, even if their expressive pressure minima at a flight altitude of about $10000 \mathrm{~m}$ a.s.l. has higher values than the lowest pressure minimum achieved during the trekking ascent to an altitude of $4100 \mathrm{~m}$ a.s.l. (in the middle of the curve in Fig. 7). This is due to overpressure conditions in the aircraft. Equally, there are easily identified areas in Nepal itself on the barometric pressure course (Figs. 7-9), e.g. the higher-lying Kathmandu plateau (around $1600 \mathrm{~m}$ a.s.l.), and the low-lying river valleys (around $300 \mathrm{~m}$ a.s.l.) on the road leading from Kathmandu to Pokhara, as well as the depression at Pokhara itself (around $1000 \mathrm{~m}$ a.s.l.) and the nearby lake (Fig. 2). From there, the gradual ascent follows up the Kali Gandaki River valley between the Dhaulagiri and the Annapurna massifs to the Muktinath monastery (around $3800 \mathrm{~m}$ a.s.l.) at the Upper Mustang border and to the altitude point of $4100 \mathrm{~m}$ a.s.l. below the Thorung La Pass (5416 m a.s.l.). The crossings of the deep valleys of the Trishuli and Marsyangdi rivers (around $300 \mathrm{~m}$ a.s.l.) on the road between Kathmandu and Pokhara, and the crossings of 
mountain ranges, e.g. on the road between Pokhara and Baglung (around $1800 \mathrm{~m}$ a.s.l.) as well as the ascent to the Sarangkot observation hill (around $1590 \mathrm{~m}$ a.s.l.) near Pokhara are detected on the barometric pressure curve.

The basic statistical characteristics of the meteorological parameters for individual destinations and environments are presented in Table 1.

Table 1. Basic statistical characteristics of meteorological parameters for single destinations and environments.

\begin{tabular}{|c|c|c|c|c|c|c|}
\hline & $\begin{array}{l}\text { No. of measure- } \\
\text { ments (à } 4 \text { min) }\end{array}$ & Minimum & Maximum & Mean & $\begin{array}{l}\text { Standard } \\
\text { deviation }\end{array}$ & $\begin{array}{l}\text { Coefficient } \\
\text { of variation }\end{array}$ \\
\hline \multicolumn{7}{|c|}{ TEMPERATURE $\left({ }^{\circ} \mathrm{C}\right)$} \\
\hline $\begin{array}{l}\text { Bratislava } \\
\text { (Slovakia) }\end{array}$ & 1359 & 12.4 & 23.9 & 19.2 & 2.0 & 0.11 \\
\hline \begin{tabular}{|l|} 
Dubai (United \\
Arab Emirates)
\end{tabular} & 321 & 15.0 & 22.9 & 21.2 & 1.5 & 0.07 \\
\hline Nepal & 4750 & 13.8 & 40.6 & 22.3 & 3.8 & 0.17 \\
\hline aircraft flights & 304 & 15.3 & 23.6 & 22.0 & 0.7 & 0.03 \\
\hline \multicolumn{7}{|c|}{ HUMIDITY (\% r.h.) } \\
\hline $\begin{array}{l}\text { Bratislava } \\
\text { (Slovakia) }\end{array}$ & 1359 & 38.9 & 67.5 & 51.4 & 2.9 & 0.05 \\
\hline \begin{tabular}{|l|} 
Dubai (United \\
Arab Emirates)
\end{tabular} & 321 & 39.5 & 67.5 & 55.2 & 0.7 & 0.02 \\
\hline Nepal & 4750 & 9.8 & 84.4 & 58.1 & 10.6 & 0.18 \\
\hline aircraft flights & 304 & 39.5 & 67.9 & 55.0 & 0.4 & 0.01 \\
\hline \multicolumn{7}{|c|}{ AIR PRESSURE (hPa) } \\
\hline $\begin{array}{l}\text { Bratislava } \\
\text { (Slovakia) }\end{array}$ & 1359 & 999.6 & 1017.8 & 1007.6 & 1.5 & 0.002 \\
\hline \begin{tabular}{|l|} 
Dubai (United \\
Arab Emirates)
\end{tabular} & 321 & 1000.9 & 1023.6 & 1010.3 & 1.6 & 0.002 \\
\hline Nepal & 4750 & 673.9 & 982.1 & 878.1 & 60.5 & 0.07 \\
\hline \begin{tabular}{|l} 
aircraft flights \\
\end{tabular} & 304 & 788.9 & 1012.2 & 828.8 & 50.6 & 0.06 \\
\hline
\end{tabular}

\subsection{Equivalent gamma dose rate}

The overall equivalent gamma dose rate course (Fig. 8) reflects changes in the ambient radioactivity of the studied destinations. Besides the natural gamma radiation of the surrounding geological and non-geological environment, its the most important component is the gamma component of cosmic radiation. These radioactivity components could not be separated by the 
instruments that were used.

Based on the overall curve, it can be concluded that the lowest values of the equivalent gamma dose rate are connected with the Dubai environment, where they are bound to large complexes of the Quaternary sandy cover formations (Price et al., 2012), with the typically low content of radioactive elements (IAEA, 1990), as well as to the low contribution of cosmic radiation in consideration of the very low altitude of around $15 \mathrm{~m}$ a.s.l. (IAEA, 1990).

The higher values of the equivalent gamma dose rate are valid for the region of Bratislava near its airport. This area is composed of Quaternary clayey cover (Geological map of Slovakia 1:50 000, 2013) with a higher content of a generally more radioactive clay component (IAEA, 1990); but it also lies at a higher altitude (around $130 \mathrm{~m}$ a.s.l.), with an appropriately higher degree of cosmic radiation (IAEA, 1990) in comparison with Dubai.

Even higher values of the equivalent gamma dose rate were registered

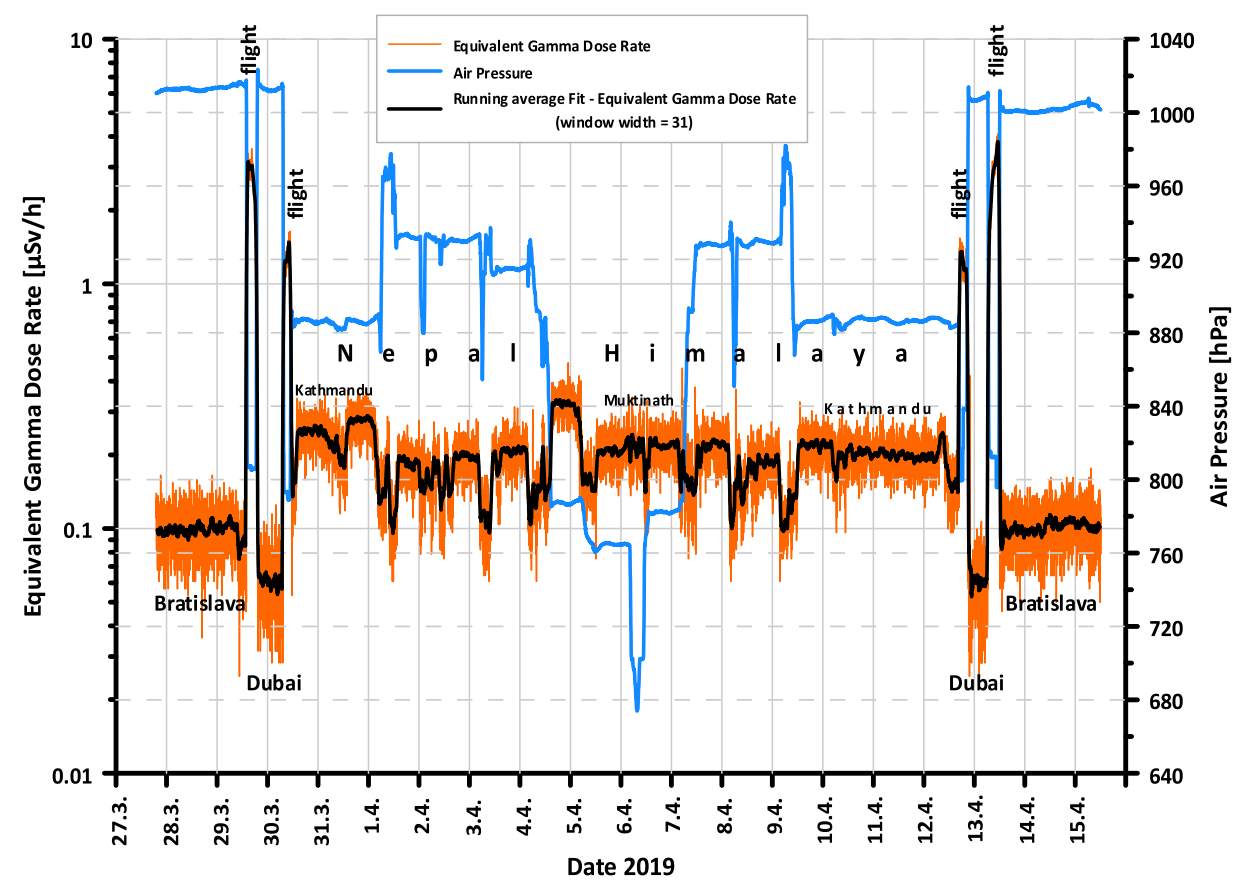

Fig. 8. Overview of the equivalent gamma dose rate and barometric pressure courses during the entire trip. 
along the study transect through the Nepal Himalaya, where on one hand the surrounding mountain environment is comprised to a great extent by parent rocks and their fresh weathered cover with a possibly higher content of radionuclides, while on the other hand the contribution of cosmic radiation is even higher as a result of the high average altitude (IAEA, 1990).

The highest values by far of the equivalent gamma dose rate were detected during four international aeroplane flights (Bratislava - Dubai, Dubai - Kathmandu and back) with the highest degree of cosmic radiation at altitudes of around $10000 \mathrm{~m}$ a.s.l.

The basic statistical characteristics of the equivalent gamma dose rate for individual destinations and environments are presented in Table 2.

Table 2. Basic statistical characteristics of the equivalent gamma dose rate for individual destinations and environments.

\begin{tabular}{|c|c|c|c|c|c|c|}
\hline & $\begin{array}{c}\text { No. of measure- } \\
\text { ments (à 2 min })\end{array}$ & $\begin{array}{l}\text { Minimum } \\
(\mu \mathrm{Sv} / \mathrm{h})\end{array}$ & $\begin{array}{l}\text { Maximum } \\
(\mu \mathrm{Sv} / \mathrm{h})\end{array}$ & $\begin{array}{c}\text { Mean } \\
(\mu \mathrm{Sv} / \mathrm{h})\end{array}$ & $\begin{array}{c}\text { Standard } \\
\text { deviation } \\
(\mu \mathrm{Sv} / \mathrm{h})\end{array}$ & $\begin{array}{l}\text { Coefficient } \\
\text { of variation }\end{array}$ \\
\hline $\begin{array}{c}\text { Bratislava } \\
\text { (Slovakia) }\end{array}$ & 2715 & 0.025 & 0.176 & 0.099 & 0.020 & 0.199 \\
\hline $\begin{array}{c}\text { Dubai (United } \\
\text { Arab Emirates })\end{array}$ & 637 & 0.025 & 0.097 & 0.061 & 0.022 & 0.349 \\
\hline Nepal & 9502 & 0.053 & 0.476 & 0.199 & 0.055 & 0.279 \\
\hline aircraft flights & 611 & 0.057 & 4.126 & 1.733 & 0.745 & 0.419 \\
\hline
\end{tabular}

\subsection{International flights and the equivalent gamma dose rate}

The highest values of the equivalent gamma dose rate were registered during four international flights as a result of the high contribution of cosmic radiation at flight altitudes of around $10000 \mathrm{~m}$ a.s.l. The detector was placed in the luggage compartment of aeroplane during the entire flight time. The maximum value $(4.126 \mu \mathrm{Sv} / \mathrm{h})$ and average value $(1.733 \pm 0.745 \mu \mathrm{Sv} / \mathrm{h})$ of the equivalent gamma dose rate during flights (Table 2) comply with official data stated by aircraft crews for flights at altitudes of up to $16500 \mathrm{~m}$ (EURADOS WG5, 2004), monitored from 1992 to 2003, with an average value of $3.8 \pm 0.8 \mu \mathrm{Sv} / \mathrm{h}$, the most frequent measured value of $2.5 \pm 0.5 \mu \mathrm{Sv} / \mathrm{h}$ and the maximum value of $19.2 \pm 12.4 \mu \mathrm{Sv} / \mathrm{h}$. The probable reason for the lower values in our case was the registration of gamma radiation only, while 
in the case of the EURADOS study, the complex sun and galactic cosmic radiation was a subject of interest (EURADOS WG5, 2004). In terms of safety and protection against radiation, the mean value of the effective dose obtained during the overall flight time (20.8 hours) at the level of $0.036 \mathrm{mSv}$ $(1.733 \mu \mathrm{Sv} / \mathrm{h} \times 20.8 \mathrm{~h}=36 \mu \mathrm{Sv}=0.036 \mathrm{mSv})$ was absolutely safe as one would have to undergo at least 300 flight hours at altitudes of over $9144 \mathrm{~m}$ in the equatorial zone (Beck et al., 2006), where our flights were undertaken to achieve the limit of the annual effective dose valid for the population at the level of $1 \mathrm{mSv} /$ year (Council Directive 2013/59/EURATOM, 2014).

\subsection{The Nepal Himalaya environment}

On the basis of a more detailed view of the time course of the equivalent gamma dose rate (Fig. 9) and the barometric pressure (Figs. 7,9), it is possible to state that these variables also depict some environmental changes within transfers in the Nepal Himalaya area itself (Fig. 2).

Considering the fact that the measured variables are presented in a time course and not a distance course, the longer one stays in one place (usually in accommodations) form the more relatively stable parts, where the values oscillate around the mean value, while car transfers to other accommodation places, usually accompanied by short stops at geologically interesting localities and outcrops, appear as shorter parts of lowered and less stable values of the equivalent gamma dose rate.

Repeated stays in some places, e.g. in the Kathmandu and Pokhara regions (on the way there and back), show approximately the same levels of the equivalent gamma dose rate. It is more evident for the Pokhara area (on average $0.178 \mu \mathrm{Sv} / \mathrm{h}$ on the way there versus $0.177 \mu \mathrm{Sv} / \mathrm{h}$ on the way back), than for the Kathmandu area (on average $0.242 \mu \mathrm{Sv} / \mathrm{h}$ on the way there versus $0.201 \mu \mathrm{Sv} / \mathrm{h}$ on the way back), where the equivalent gamma dose rate values increased significantly (up to $0.375 \mu \mathrm{Sv} / \mathrm{h}$ ) during the first stay during and after a strong thunderstorm on 31 March 2019 as a result of radon gas washing from the atmosphere to the earth's surface (Fig. 9). This rainstorm is documented by the highest measured values of air humidity (up to $84.4 \%$ r.h.) during the entire trip (Fig. 7 ). This was the only single, unstable meteorological event during the entire trip. The well-marked decrease of the equivalent gamma dose rate values immediately before the storm (to 
the level of $0.115 \mu \mathrm{Sv} / \mathrm{h}$ ) was probably caused by the composition of building material in the vicinity of Durbar Square in the centre of Kathmandu (Fig. 9). The higher average values of the equivalent gamma dose rate in the Kathmandu region $(0.222 \mu \mathrm{Sv} / \mathrm{h})$ in comparison with the Pokhara region $(0.178 \mu \mathrm{Sv} / \mathrm{h})$ could have been due to the commonly higher radioactivity of the Pre-Cambrian to Devonian metamorphites (phyllites and shales) of the Higher Himalaya's Kathmandu Group, while the Pokhara area is comprised of Proterozoic, mostly sedimentary rocks (limestones, dolomites) and lowgrade metamorphed rocks (quartzites) of the Lesser Himalaya sequences, with commonly low radioactivity.

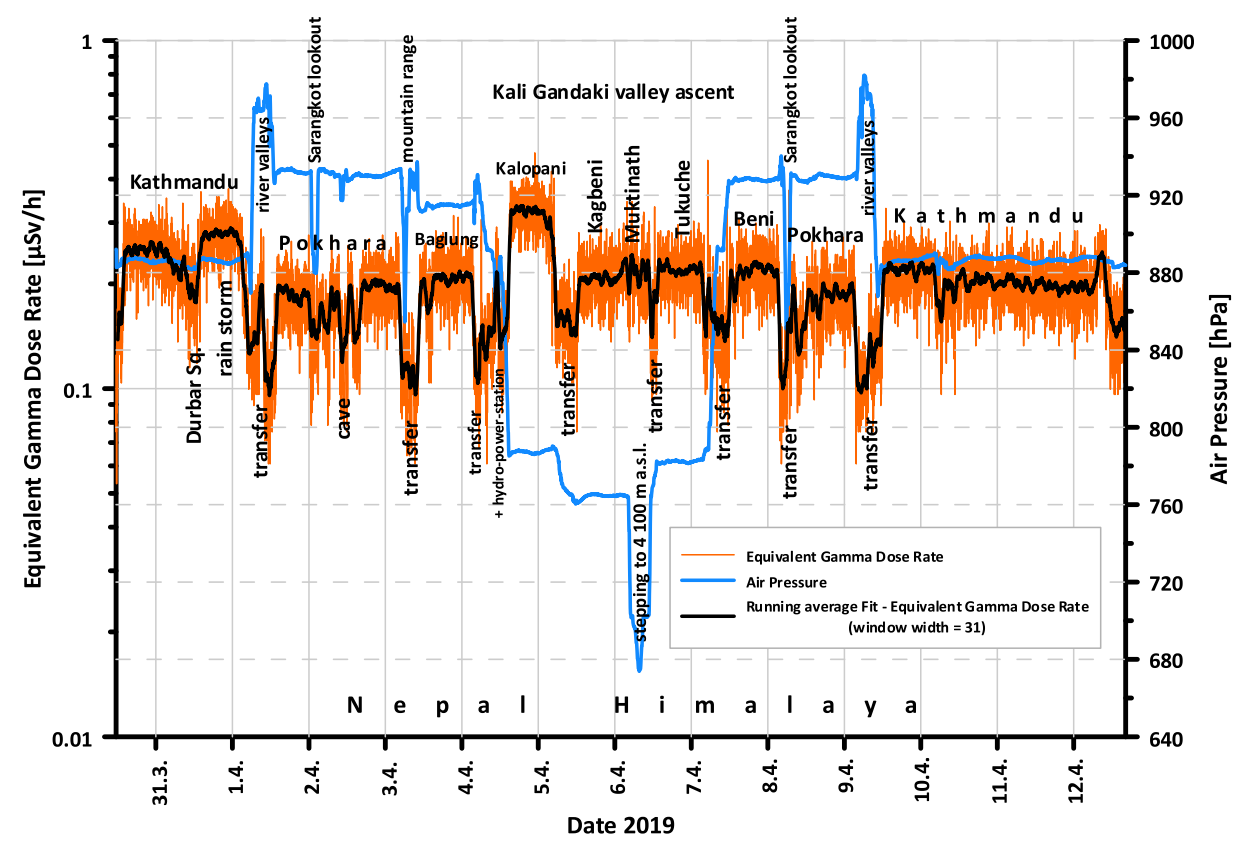

Fig. 9. Time courses of the equivalent gamma dose rate and barometric pressure in detail for the Nepal Himalaya part.

The transfer from the Kathmandu plateau to the Pokhara depression and back is indicated by short but distinct decreases in barometric pressure values (Figs. 7-9) when crossing the mountain range encircling Kathmandu, followed by stages of expressive increases in barometric pressure values when travelling along the deep valleys of the Trishuli, Marsyangdi and Seti Rivers 
on the way to Pokhara.

In a similar way, due to the sharp minima of barometric pressure (Figs. 79), the ascents to Sarangkot lookout hill site (1590 m a.s.l.) in the Pokhara area, as well as the crossings of the mountain range on the way from Pokhara to Baglung (around $1800 \mathrm{~m}$ a.s.l.) are also indicated.

Starting from Pokhara, a sequential decrease of barometric pressure is recorded in connection with the gradual ascent following the Kali Gandaki River valley between the Dhaulagiri and the Annapurna massifs up to its lowest value of $673.85 \mathrm{hPa}$ at the highest point - the Muktinath monastery (around $3800 \mathrm{~m}$ a.s.l.) and the altitude of $4100 \mathrm{~m}$ a.s.l. below the Thorung La Pass (5416 $m$ a.s.l.).

The Baglung surroundings are also comprised of rock sequences of the Lesser Himalaya zone with an average equivalent gamma dose rate value $(0.202 \mu \mathrm{Sv} / \mathrm{h})$ near the Pokhara area.

The section of lower equivalent gamma dose rate values (on average $0.145 \mu \mathrm{Sv} / \mathrm{h}$ ), belonging to the transfer from Baglung to Kalopani, contains a peak of higher values (on average $0.291 \mu \mathrm{Sv} / \mathrm{h}$ ) obtained during the guided tour of the inflow underground tunnel of the hydroelectric power station of the Mistri Khola Hydroelectric Project.

After crossing the Main Central Thrust (MCT) zone in the area of the village of Dana (Figs. 2 and 6a) the geological surroundings are formed by the Neo-Proterozoic rocks of the Higher Himalaya zone, which are represented by mica-schists alternating with banded gneisses, migmatites and granites showing the highest equivalent gamma dose rate values (maximally up to $0.476 \mu \mathrm{Sv} / \mathrm{h}$, on average $0.343 \mu \mathrm{Sv} / \mathrm{h}$ ) in the section of the villages of Tatopani, Dana and Kalopani.

After crossing the tectonic boundary of the South Tibetan Detachment System (STDS) between the villages of Kalopani and Larjung, the Tethyan Himalayan sequence of terrigenous and carbonate sediments such as sandstones, siltstones, dolomites, limestones and shales starts and continues further to the north. These rocks form the highest mountain peaks in the surroundings (Dhaulagiri $-8167 \mathrm{~m}$ a.s.l., Tukuche Peak $-6920 \mathrm{~m}$ a.s.l., Annapurna - $8091 \mathrm{~m}$ a.s.l., Nilgiri - $7061 \mathrm{~m}$ a.s.l., Tilicho Peak - $7134 \mathrm{~m}$ a.s.l. and others). The most remote points of the tour - the Muktinath monastery and the mountain stepping to $4100 \mathrm{~m}$ a.s.l. also lay in this geological environment. Sedimentary rocks show lower values of the dose equivalent rate 
in the Kagbeni area (on average $0.210 \mu \mathrm{Sv} / \mathrm{h}$ ) and Muktinath (on average $0.223 \mu \mathrm{Sv} / \mathrm{h}$ ) as well as in the Tukuche area (on average $0.221 \mu \mathrm{Sv} / \mathrm{h}$ ) on the way back from Muktinath.

The part with the highest measured equivalent gamma dose rate values (Kalopani - Dana - Tatopani) of the Higher Himalaya rocks did not show higher values on the way back. This was probably due to the fast vehicle transport, despite the fact that the short measurements at orthogneiss outcrops showed high equivalent gamma dose rate values (up to $0.453 \mu \mathrm{Sv} / \mathrm{h}$ ).

The Beni area again formed by rock sequences of the Lesser Himalaya zone showed the same equivalent gamma dose rate values (on average $0.217 \mu \mathrm{Sv} / \mathrm{h})$ as in nearby Baglung $(0.202 \mu \mathrm{Sv} / \mathrm{h})$.

\section{Conclusions}

The recording measurements of ambient radioactivity in the form of the equivalent gamma dose rate in the air taken on the tour dedicated to the reconnaissance comparative study of the Alpine-Carpathian and Himalayan mountain range systems on the way from Bratislava (Slovakia) - Dubai (United Arab Emirates) - Kathmandu (Nepal) - Nepal Himalaya and back showed the presence of different equivalent gamma dose rate levels between particular destinations and environments and the possibility of the registration of their changes by the above-mentioned instruments. The differences were based on both the composition of the natural environment (geological and non-geological), and the varying contribution of cosmic radiation depending on altitude. The lowest registered equivalent gamma dose rate values were recorded in the Dubai environment (UAE); a higher equivalent gamma dose rate values were recorded in the Bratislava region (Slovakia) and even higher values of the entire study geological transect were recorded in the Nepal Himalaya environment. By far the highest equivalent gamma dose rate values were registered during the four international aeroplane flights at high altitudes; however, the effective dose value did not exceed the obligatory limits for safe exposure of the common population. The results confirm the generally known facts about the dependence of cosmic radiation growth on altitude increase, and the growth of geological environment radioactivity in the following sequence: sandy formations - clayey formations - weathered and non-weathered sequences of parent rocks. 
Acknowledgements. The authors are grateful for the support by the Slovak Research and Development Agency APVV under grant APVV-16-0146 and APVV-150050. This work was supported also by the Slovak Grant Agency VEGA, under grant 2/0006/19. The Slovak authors are also very grateful for the accompanying support by Assist. Prof. Ashok Sigdel and Dr. Subash Acharya from the Central Department of Geology, Tribhuvan University, Kathmandu.

\section{References}

Beck P., Bartlett D., Lindborg L., McAulay I., Schnuer K., Schraube H., Spurný F., 2006: Aircraft crew radiation workplaces: comparison of measured and calculated ambient dose equivalent rate data using the Eurados in-flight radiation database. Radiat. Prot. Dosim., 118, 2, 182-189, doi: 10.1093/rpd/ncl029.

Council Directive 2013/59/EURATOM of 5 December 2013 stipulating the basic safety standards for protection against the dangers arising from exposure to ionising radiation. Official Journal of the European Union, L 13/1, 17.1.2014, 73 p.

Dhital M. R., 2015: Geology of the Nepal Himalaya. Springer, 498 p.

EURADOS WG5, 2004: Cosmic radiation exposure of aircraft crew. Compilation of measured and calculated data. Final report. Radiation Protection, Issue 140, Luxembourg, 271 p., online, available at http://europe.eu.int.

Geological map of Slovakia 1:50000, 2013: State Geological Institute of Dionýz Štúr, Bratislava, online, available at http://apl.geology.sk/gm50js on 13.1.2020.

Himalayan Map House Pvt. Ltd., 2014: The Geological Map of Nepal, 1:1000 000.

IAEA, 1990: The Use of Gamma Ray Data to Define the Natural Radiation Environment. IAEA-TECDOC-566, Vienna, 48 p.

Internet 1: Geology of Emirates. Available at http://www.angelfire.com/az3/mohgame il/emirates.html on 13.1.2020.

Internet 2: United Arab Emirates, Ministry of Energy and Industry, Geology and Mineral Resources Department: Geological Passport, Abu Dhabi. Available at https://www . moei.gov.ae/assets/9ad782cf/geological_passport.aspx on 13.1.2020.

Irani F. N., 2001: Geology of the United Arab Emirates. Schlumberger Drilling and Measurements, Abu Dhabi, 143 p.

Price S. J., Farrant A. R., Thomas R. J., Ellison R. A., 2012: Geology of the Dubai, Sharjah and Sir Bu N'Air 1:100 000 map sheet, 100-5, United Arab Emirates. Nottingham, UK, British Geological Survey, 54 p. 